\title{
SKIP METASTASES IN PAPILLARY THYROID CARCINOMA - PREVALENCE, PREDICTIVE AND CLINICOPATHOLOGICAL FACTORS
}

\author{
Borna Miličić ${ }^{1}$, Ratko Prstačić ${ }^{1,2}$ and Drago Prgomet ${ }^{1,2}$ \\ ${ }^{1}$ Department of Ear, Nose, Throat, and Head and Neck Surgery, Zagreb University Hospital Centre; \\ ${ }^{2}$ School of Medicine, University of Zagreb
}

\begin{abstract}
SUMMARY - Background: Cervical lymph node metastases are frequently found in papillary thyroid carcinoma (PTC) and occur in a stepwise fashion. Skip metastases that omit the central compartment and spread initially in lateral neck levels are present in a certain share of patients, and their significance is poorly understood. The aim of this prospective study was to identify their possible predictors and clinicopathological factors in a group of patients with PTC with lateral lymph node (LLN) metastases. Methods: We enrolled 68 patients with PTC with preoperatively evaluated LLN metastases who underwent total thyroidectomy with lateral lymph node dissection between 2011 and 2018. We analysed the clinicopathological features and pattern of dissemination of continuous and skip metastases. Results: The prevalence of skip metastases was $23.5 \%$. Compared with the continuous metastases group, the patients were older, had primary tumors that were more often situated unilaterally, and had smaller primary tumor size. Level II was less often involved, and none of the patients with skip metastases had all LNN positive $(\mathrm{p}=0.05)$. Conclusion: Skip metastases occur more frequently in older patients and display certain clinicopathological features like smaller size of the primary tumor and dissemination in less lateral neck levels. In the view of the fact that they are found rather frequently, lateral neck regions should be meticulously investigated in patients with PTC without central lymph node (CLL) metastases.
\end{abstract}

Key words: skip metastases, clinicopathological features, papillary thyroid carcinoma, lateral neck metastases

\section{Introduction}

Cervical lymph node metastases are relatively common in papillary thyroid cancer (PTC) (1) and occur in $30-80 \%$ of patients (2). They have a characteristic way of disseminating initially in the pretracheal, paratracheal, and upper mediastinal lymph nodes (central neck lymph nodes, CLN). Afterwards, tumor cells spread to ipsilateral neck lymph nodes (LLN), levels II to V. Finally, they disseminate in contralateral lymph nodes of the neck (3-7). There is also an unconven-

Corresponding author: Borna Miličic, $M D$, Department of Ear, Nose, Throat, and Head and Neck Surgery, Zagreb University Hospital Centre, Kišpatićeva 12, 10000 Zagreb, Croatia

E-mail address: borna.milicic0@gmail.com tional pathway in which tumor cells omit the CLL and metastases first occur in LLN $(8,9)$. This kind of metastases is termed a skip metastasis, and it is hypothesized that they display different clinicopathological features compared with continuous metastases (10) and therefore have a different prognosis (11). There are several studies and meta-analyses in the literature regarding PTC skip metastases, but they were either performed on a smaller number of patients or larger groups from multiple hospitals; some of them with recurring patients and/or treated by different surgeons (12-14). The aim of our study was to determine the general occurrence, predictors, and association of skip metastases with certain clinicopathological features in a group of patients with primary PTC with proven 
LLN metastases. Our results will provide further insight into management options and altering the treatment according to our findings.

\section{Patients and methods}

This prospective study was approved by the local Institutional Review Boards. We enrolled all patients with PTC who had LLN metastases. The patients were surgically treated between 2011 and 2018 at the University Hospital Centre, Department of Otolaryngology, Head and Neck Surgery. All surgeries were carried out by the same surgeon. All of the patients had previously untreated PTC with LLN metastases, preoperatively confirmed and evaluated by ultrasonography (US) for tumor size, location, and the presence of lymph node metastases (LNM). LNM were afterwards investigated with fine needle aspiration biopsy (FNAB). Exclusion criteria were prior thyroid surgery or radiotherapy, extensive PTC with distant metastases, or other thyroid malignancy. The patients underwent total thyroidectomy alongside with CLN and LLN dissection. Levels of the neck were categorized according to the American Head and Neck Society (15). Specimens were afterwards subjected to pathological analysis (PA). Skip metastases are defined as lateral lymph node metastasis with no positive nodes in the central compartment. Extracapsular spread refers to spreading beyond the lymph node capsule. All results are presented as mean +/- SD if not stated otherwise.

\section{Ethics}

This study was approved by the Zagreb University Hospital Centre Bioethical Board adhering to the Helsinki Declaration of 2013. All patients have read and signed a written consent document.

\section{Statistics}

SPSS version 14 (IBM, Chicago, IL, USA) was used to perform statistical analysis. Associations between skip metastases in the LLN and several clinicopathologic factors were assessed with univariate analyses using the Pearson Chi-square test or the Fishers exact test. Continuous variables, such as primary tumor size and number of positive lymph nodes according to the presence or absence of skip metastasis were evaluated using the t-test. Statistical significance was defined as $\mathrm{P}<0.05$.

\section{Results}

\section{Patient demographics}

Out of 100 patients, 68 met the requirements for our study. Out of 32 patients that did not meet the requirements, 15 underwent surgery prior to the study, 9 underwent radiotherapy, 7 underwent surgery and radiotherapy, and one had an extensive tumor with distant metastases. Mean age was 36.5 years (range 1174 ) and the male to female ratio was $1: 4$ (17 vs 51 ). The mean primary tumor size was $2.04 \mathrm{~cm}( \pm 1.65$, range $0.2-7.0 \mathrm{~cm}) ; 26.5 \%$ percent of tumors were smaller than $1 \mathrm{~cm}$ in diameter. Tumors were mostly situated in the right lobe (44.11\%) while localization in the left lobe was observed in $26.4 \%$ of the patients and bilateral location in $29.4 \%$ of the patients. Multicentric growth was found in $73 \%$ of the patients.

Mean number of total dissected lateral lymph nodes was $33.73( \pm 17.66$, range $10-107)$, while the number of positive nodes was $5.07( \pm 4.03$, range 1-19).

Level III was involved most often (79.4\%), followed by level IV, level II, and V (Table 1). Skip metas-

Table 1. Demographics and clinical characteristics

\begin{tabular}{|l|l|}
\hline Variables & Results \\
\hline Age & $36.5 \pm 16.3(11-74)$ \\
Gender & \\
Male & $25 \%$ \\
Female & $75 \%$ \\
Mean primary tumor size & $2.04 \mathrm{~cm}^{*} \pm 1.66(0.2-7.0)$ \\
Microcarcinoma & $35.3 \%$ \\
Localization & \\
Left & $26.47 \%$ \\
Right & $44.11 \%$ \\
Bilateral & $29.41 \%$ \\
Multifocality & $73.5 \%$ \\
Extrathyroidal spread & $54.4 \%$ \\
Level II & $48.5 \%$ \\
Level III & $79.4 \%$ \\
Level IV & $73.5 \%$. \\
Level V & $30.0 \%$ \\
\hline
\end{tabular}


Table 2. Clinicopathological factors of skip compared with continuous $L L N$ metastases

\begin{tabular}{|l|l|l|l|}
\hline Variables & Skip metastases & Continuous metastases & $\mathrm{p}$ value \\
\hline Total (n=68) & $23.5 \%$ & $76.5 \%$ & \\
Mean age & $54.0 \pm 16.7$ & $33 \pm 15.26$ & $\mathrm{p}=0.02^{*}$ \\
$>45$ & $62.5 \%$ & $30.7 \%$ & $\mathrm{p}=0.042^{*}$ \\
Gender (\%men) & $31.25 \%$ men & $23 \%$ men & $\mathrm{p}=0.06$ \\
Localization & & $25 \%$ & $\mathrm{p}=0.62$ \\
Left & $31.25 \%$ & $42.3 \%$ & $\mathrm{p}=0.68$ \\
Right & $50 \%$ & $32.7 \%$ & $\mathrm{p}=0.014^{*}$ \\
Bilateral & $18.75 \%$ & $2.211 \mathrm{~cm} \pm 1.81$ & $\mathrm{p}=0.13$ \\
Tumor size & $1.49 \mathrm{~cm} \pm 0.78$ & $25 \%$ & $\mathrm{p}=0.620$ \\
Microcarcinoma & $31.25 \%$ & $76.9 \%$ & $\mathrm{p}=0.33$ \\
Multicentric & $62.5 \%$ & $53.84 \%$ & $\mathrm{p}=0.86$ \\
Extrathyroidal spread & $56.25 \%$ & & $\mathrm{p}=0.7$ \\
Lateral LN & & $1778(34.20 \pm 18.7)$ & $\mathrm{p}=0.1$ \\
Total & $516(\mathrm{mean} 32.25 \pm 14.14)$ & \\
Metastatic & $58 \pm(11.24 \%)$ & $278 \pm(16.14 \%)$ & $\mathrm{p}=0.006 *$ \\
Metastatic nodes & & $57.60 \%$ & $\mathrm{p}=0.05^{*}$ \\
Level II & $18.75 \%$ & $84.60 \%$ & $\mathrm{p}=0.25$ \\
Level III & $62.5 \%$ & $76.92 \%$ & $\mathrm{p}=0.97$ \\
Level IV & $62.5 \%$ & $30.70 \%$ & $\mathrm{p} 0.05 *$ \\
Level V & $31.25 \%$ & $17.30 \%$ & $\mathrm{p}=0.86$ \\
All levels positive & $0.0 \%$ & $53.84 \%$ & \\
Extracapsular (LN) & $54.9 \%$ & & \\
\hline
\end{tabular}

tases were present in $23.5 \%$ of patients. There were 8 patients $(11.8 \%)$ with false-negative ultrasonography finding of the central neck levels prior to pathological analysis.

\section{Prevalence and distribution of skip metastasis on the lateral neck}

We compared the clinicopathological characteristics of patients with skip and continuous metastases (Table 2). Patients with skip metastases were significantly older (median age: 54 vs 33 years). Skip metastases were more common in men than in women (31.25\% vs $23.0 \%)$.

Regarding tumor localization, we did not find a significant difference in prevalence of localization in either lobe, but the primary tumors with skip metastases showed a trend of being situated bilaterally less often $(18.75 \%$ vs $32.70 \%)$. The mean size of primary tumors was smaller in the skip metastases group (1.49 $\mathrm{cm}$ vs $2.21 \mathrm{~cm})$. There was however no significant dif- ference in microcarcinoma frequency between the two groups. The number of harvested lateral lymph nodes was similar (32.25\% vs $34.20 \%)$, but the mean number of positive nodes was smaller in the skip group. (11.24\% skip vs $16.14 \%$ continuous). In contrast to the continuous metastases group, LNN in the skip metastases group had a smaller proportion of positive nodes in each level, especially in level II ( $\mathrm{p}=0.006)$ and somewhat in level III ( $\mathrm{p}=0.05)$ (Table 2). Moreover, none of the patients in that group had all LLN levels positive, while $17,3 \%$ of patients in the continuous metastases group had all LLN levels positive $(\mathrm{p}=0.05)$.

Frequencies of tumors with extrathyroidal growth and positive lymph nodes with extracapsular spread of metastases were similar in both groups.

\section{Discussion}

The thyroid gland has an extensive and rich lymphatic drainage which makes predicting metastases 
dissemination quite challenging. It is generally accepted that tumor cells spread in a stepwise fashion: initially into pretracheal, paratracheal, and upper mediastinal LN, then into ipsilateral neck lymph nodes, and finally to contralateral neck regions (6). Some authors even theorized that lymphatic systems of the lobes are separated (16), but practice reveals that contralateral regional metastases are possible (17). Skip metastases, which initially disseminate in the lateral region, are not so rare, and they occur in $6.5-27.5 \%$ of $\mathrm{PTC}$ with LLN metastases $(8,14,18-20)$. Our result (23\%) falls into the upper end of that range. Ito et al. even proposed that continuous spread does not exist and that there is an equal chance for continuous and skipping dissemination. Their explanation was based on the finding that the percentage of solely LLN and CLN metastases was similar (18.1\% vs $22.9 \%)$. In another study by Ito, it was $29.0 \%$ vs $33.3 \%(21,22)$.

LLN metastases in PTC are associated with a higher risk of regional recurrence $(9,23)$. Re-operation increases the risk of intra- and postoperative complications as well as overall medical costs $(3,4,24,25)$; surgeons are therefore confronted with the question whether to perform para- and pretracheal dissection in patients with present LLN metastases and absent CLN metastases. The significance of PTC skip metastases is still not fully understood, and their wide range of prevalence between different studies could be a result of studies which were limited by low patient numbers and the inclusion of primary and recurrent patients in their research populations (26).

Our results show that the mean number of harvested positive LLN was smaller in the skip metastases group and that there was a tendency of fewer positive nodes in each level. Another finding of ours is that none of the patients with skip metastases had all LLN positive, while that was not the case in the continuous metastases group. We did not find such data in similar studies on PTC with skip metastases, but this can be explained by characteristics of PTC skip metastases that seem to induce better prognosis $(8,14)$.

According to some theories, PTC skip metastases occur when the primary tumor is situated in the upper poles of the thyroid gland, where the lymphatic drainage follows the pathway of the upper thyroid artery. Another possibility is that it spreads per continuitatem in the lateral regions $(27,28)$. In our case, it is evident that mostly middle and lower LLN levels were affect- ed in the skip group, and especially level II (and to some extent level III) had significantly fewer positive nodes (Table 2). This is different from studies which stated that skip metastases disseminated more frequently in level II (14), possibly as a result from the aforementioned hypothetic lymphatic drainage situated around superior thyroid artery $(14,29)$. In all our patients, we found skip metastases only in level II a and none in level IIb. From our results, it is clear that continuous metastases - as compared with skip metastases - disseminate more evenly in all LLN levels.

We obtained a similar number of lymph nodes in each patient group, therefore excluding the probability of false-negative data as a result of inadequate lymph node sampling or possible previous surgeries.

Primary tumor size was another clinicopathological feature which showed a trend of being smaller in the skip group. Similar results can be seen in most of the studies in the literature, with the tumor size being inversely associated with the probability of skip metastases $(11,14,26)$.

Over $70 \%$ of all our patients had multifocal tumor growth, which is quite a high percentage as compared with other studies (30). Multifocality was, however, less often present in patients with skip metastases, which is to some extent similar to findings by Nie et al. (11). Extracapsular LN spread was another factor inversely correlated with skip metastases in a study by Lim and Koo (26), but we did not find significant differences between our groups. These facts have led to several authors concluding that skip metastases could mean better prognosis and could be associated with less aggressive forms of PTC $(8,11)$. This would in fact be in concordance with skip metastases outcomes in other primary tumor localizations such as colorectal or small cell lung cancer, where they positively affect survival rate $(31,32)$.

In the present study, we found a significantly higher chance for skip metastases in older patients $(62.5 \%$ vs $32.7 \%, p=0.02$ ) who were above 45 years of age. It is known that higher age is negatively correlated with prognosis in PTC $(33,34)$ and that it does not affect the tumor metastasizing potential significantly (35), which is contradictory to the previously mentioned hypothesis $(8,11)$. On the other hand, studies have also shown that there is a smaller chance for continuous LLN metastases in older patients (36). 
Possible limitations of our study include the lack of information on the exact tumor location in the thyroid gland. However, we found a smaller proportion of bilateral tumors in the skip metastases group. Some studies found localization in upper lobe to be associated with skip metastases $(13,14)$, but that was also demonstrated for increased frequency of continuous LNM in other studies (37). Another possible drawback is the fact that lateral neck dissection (levels IIIV) which we performed was therapeutical rather than prophylactic. According to one study, latent LLN metastases which were not found preoperatively clinically nor with US were found after PA in over $50 \%$ of patients who underwent prophylactic lateral dissection (22). Therefore, including such patients might have revealed other possible predictive factors.

\section{Conclusion}

In summary, our results showed that PTC with skip metastases tend to present different clinicopathological characteristics than PTC with continuous metastases. Primary tumors were often smaller in size, displayed bilateral growth less often, and occured more frequently in older patients. Moreover, skip metastases seem to less frequently metastasize in certain lateral neck levels, and they almost never affect all lateral neck levels.

All of this implies the need for thorough lateral neck regions investigation in patients with PTC who do not have central neck levels metastases, bearing in mind the aforementioned facts. Further prospective studies with a larger number of patients with PTC with skip metastases should be undertaken to assess the impact on patient outcomes and other possible predictive factors.

\section{Author's note}

This study was approved by the University Hospital Centre Zagreb, Zagreb, Bioethical Board adhering to the Helsinki Declaration of 2013. All of the authors have read and approved the manuscript.

\section{Declaration of conflicting interests}

The author(s) declare no potential conflicts of interest with respect to the research, authorship, and/or publication of this article.

\section{Funding}

The author(s) received no financial support for the research, authorship, and/or publication of this article.

\section{Abbreviations:}

CLL - central lymph nodes

FNAB - fine-needle aspiration biopsy

LN - lymph nodes

LLN - lateral lymph nodes

LNM - lateral neck metastases

PTC - papillary thyroid carcinoma

PA - pathological analysis

$\mathrm{SD}$ - standard deviation

US - ultrasonography

\section{References:}

1. Sivanandan R, Soo KC. Pattern of cervical lymph node metastases from papillary carcinoma of the thyroid. Br J Surg. 2001 Sep;88(9):1241-4.

2. Ar S. Management of the neck in thyroid cancer. Otolaryngol Clin North Am. 1998 Oct 1;31(5):823-31.

3. Shaha AR. Editorial: Complications of Neck Dissection for Thyroid Cancer. Ann Surg Oncol. 2008 Feb;15(2):397-9.

4. Wada N, Duh Q-Y, Sugino K, Iwasaki H, Kameyama K, Mimura $\mathrm{T}$, et al. Lymph node metastasis from 259 papillary thyroid microcarcinomas: frequency, pattern of occurrence and recurrence, and optimal strategy for neck dissection. Ann Surg. 2003 Mar;237(3):399-407.

5. Radivojević RC, Prgomet D, Markesić J, Ezgeta C. Hypocalcaemia after thyroid surgery for differentiated thyroid carcinoma: preliminary study report. Coll Antropol. 2012 Nov;36 Suppl 2:73-8.

6. Machens A, Hinze R, Thomusch O, Dralle H. Pattern of nodal metastasis for primary and reoperative thyroid cancer. World J Surg. 2002 Jan;26(1):22-8.

7. Medicinska naklada. TUMORI GLAVE I VRATA [Internet]. [cited 2020 Apr 8]. Available from: https://www.medicinskanaklada.hr/tumori-glave-i-vrata

8. Machens A, Holzhausen H-J, Dralle H. Skip metastases in thyroid cancer leaping the central lymph node compartment. Arch Surg Chic Ill 1960. 2004 Jan;139(1):43-5.

9. Roh J-L, Park J-Y, Park CI. Total thyroidectomy plus neck dissection in differentiated papillary thyroid carcinoma patients: pattern of nodal metastasis, morbidity, recurrence, and postoperative levels of serum parathyroid hormone. Ann Surg. 2007 Apr;245(4):604-10.

10. So YK, Kim M-J, Kim S, Son Y-I. Lateral lymph node metastasis in papillary thyroid carcinoma: A systematic review and meta-analysis for prevalence, risk factors, and location. Int J Surg Lond Engl. 2018 Feb;50:94-103. 
11. Nie X, Tan Z, Ge M. Skip metastasis in papillary thyroid carcinoma is difficult to predict in clinical practice. BMC Cancer. 2017 Oct 25;17(1):702.

12. Chung YS, Kim JY, Bae J-S, Song B-J, Kim JS, Jeon HM, et al. Lateral lymph node metastasis in papillary thyroid carcinoma: results of therapeutic lymph node dissection. Thyroid Off J Am Thyroid Assoc. 2009 Mar;19(3):241-6.

13. Lee YS, Shin S-C, Lim Y-S, Lee J-C, Wang S-G, Son S-M, et al. Tumor location-dependent skip lateral cervical lymph node metastasis in papillary thyroid cancer. Head Neck. 2014 Jun; 36(6):887-91.

14. Park JH, Lee YS, Kim BW, Chang H-S, Park CS. Skip lateral neck node metastases in papillary thyroid carcinoma. World J Surg. 2012 Apr;36(4):743-7.

15. American Thyroid Association Surgery Working Group, American Association of Endocrine Surgeons, American Academy of Otolaryngology-Head and Neck Surgery, American Head and Neck Society, Carty SE, Cooper DS, et al. Consensus statement on the terminology and classification of central neck dissection for thyroid cancer. Thyroid Off J Am Thyroid Assoc. 2009 Nov;19(11):1153-8.

16. Fernandez-Cruz L, Astudillo E, Pera C. Lymphography of the thyroid gland: is intraglandular dissemination of thyroid carcinoma possible? World J Surg. 1977 Sep;1(5):647-54.

17. Eichhorn W, Tabler H, Lippold R, Lochmann M, Schreckenberger M, Bartenstein P. Prognostic factors determining longterm survival in well-differentiated thyroid cancer: an analysis of four hundred eighty-four patients undergoing therapy and aftercare at the same institution. Thyroid Off J Am Thyroid Assoc. 2003 Oct;13(10):949-58.

18. Bj L, Sg W, Jc L, Sm S, Ij K, Yk K. Level IIb lymph node metastasis in neck dissection for papillary thyroid carcinoma. Arch Otolaryngol Head Neck Surg. 2007 Oct 1;133(10):1028-30.

19. Bumber B, Marjanovic Kavanagh M, Jakovcevic A, Sincic N, Prstacic R, Prgomet D. Role of matrix metalloproteinases and their inhibitors in the development of cervical metastases in papillary thyroid cancer. Clin Otolaryngol Off J ENT-UK Off J Neth Soc Oto-Rhino-Laryngol Cervico-Facial Surg. 2020; 45(1):55-62.

20. Klišeska E, Makovac I. Skip Metastases in Papillary Thyroid Cancer. Coll Antropol. 2012;36 supplement 2(2):59-62.

21. Ito Y, Tomoda C, Uruno T, Takamura Y, Miya A, Kobayashi K, et al. Clinical significance of metastasis to the central compartment from papillary microcarcinoma of the thyroid. World J Surg. 2006 Jan;30(1):91-9.

22. Ito $\mathrm{Y}$, Jikuzono T, Higashiyama T, Asahi S, Tomoda C, Takamura $\mathrm{Y}$, et al. Clinical significance of lymph node metastasis of thyroid papillary carcinoma located in one lobe. World J Surg. 2006 Oct;30(10):1821-8.

23. Shaha AR. Prognostic factors in papillary thyroid carcinoma and implications of large nodal metastasis. Surgery. 2004 Feb;135(2):237-9.

24. Grabovac S, Prgomet D, Janjanin S, Hadzibegović AD. [Parathyroid hormone values in thyroid gland surgeries by harmonic scalpel and by conventional methods]. Lijec Vjesn. 2013 Dec;135(11-12):306-10.
25. Prgomet D, Janjanin S, Bilić M, Prstacić R, Kovac L, Rudes M, et al. A prospective observational study of 363 cases operated with three different harmonic scalpels. Eur Arch Oto-RhinoLaryngol Off J Eur Fed Oto-Rhino-Laryngol Soc EUFOS Affil Ger Soc Oto-Rhino-Laryngol - Head Neck Surg. 2009 Dec;266(12):1965-70.

26. Lim YC, Koo BS. Predictive factors of skip metastases to lateral neck compartment leaping central neck compartment in papillary thyroid carcinoma. Oral Oncol. 2012 Mar;48(3): $262-5$.

27. Ito Y, Miyauchi A. Lateral lymph node dissection guided by preoperative and intraoperative findings in differentiated thyroid carcinoma. World J Surg. 2008 May;32(5):729-39.

28. Prgomet D, Bilić M, Kovac L, Hutinec Z, Topić I. [Locally invasive papillary thyroid cancer--our experience]. Lijec Vjesn. 2012 Oct;134(9-10):266-70.

29. Ito Y, Tomoda C, Uruno T, Takamura Y, Miya A, Kobayashi K, et al. Papillary microcarcinoma of the thyroid: how should it be treated? World J Surg. 2004 Nov;28(11):1115-21.

30. Horvatic Herceg G, Herceg D, Kralik M, Kulic A, Bence-Zigman $\mathrm{Z}$, Tomic-Brzac $\mathrm{H}$, et al. Urokinase plasminogen activator and its inhibitor type- 1 as prognostic factors in differentiated thyroid carcinoma patients. Otolaryngol--Head Neck Surg Off J Am Acad Otolaryngol-Head Neck Surg. 2013 Oct;149(4): 533-40.

31. Prenzel KL, Mönig SP, Sinning JM, Baldus SE, Gutschow CA, Grass G, et al. Role of skip metastasis to mediastinal lymph nodes in non-small cell lung cancer. J Surg Oncol. 2003 Apr; 82(4):256-60.

32. Yamamoto Y, Takahashi K, Yasuno M, Sakoma T, Mori T. Clinicopathological characteristics of skipping lymph node metastases in patients with colorectal cancer. Jpn J Clin Oncol. 1998 Jun;28(6):378-82.

33. Cho JS, Yoon JH, Park MH, Shin SH, Jegal YJ, Lee JS, et al. Age and prognosis of papillary thyroid carcinoma: retrospective stratification into three groups. J Korean Surg Soc. 2012 Nov; 83(5):259-66.

34. Chereau N, Trésallet C, Noullet S, Godiris-Petit G, Tissier F, Leenhardt L, et al. Prognosis of papillary thyroid carcinoma in elderly patients after thyroid resection: A retrospective cohort analysis. Medicine (Baltimore). 2016 Nov;95(47):e5450.

35. Punda A, Bedeković V, Barić A, Kontić M, Čolović Z, Vanjaka Rogošić L, et al. RET expression and its correlation with clinicopathologic data in papillary thyroid carcinoma. Acta Clin Croat. 2018 Dec;57(4):646-52.

36. Wada N, Masudo K, Nakayama H, Suganuma N, Matsuzu K, Hirakawa $\mathrm{S}$, et al. Clinical outcomes in older or younger patients with papillary thyroid carcinoma: Impact of lymphadenopathy and patient age. Eur J Surg Oncol EJSO. 2008 Feb $1 ; 34(2): 202-7$.

37. Lin K-L, Wang O-C, Zhang X-H, Dai X-X, Hu X-Q, Qu $\mathrm{J}-\mathrm{M}$. The BRAF mutation is predictive of aggressive clinicopathological characteristics in papillary thyroid microcarcinoma. Ann Surg Oncol. 2010 Dec;17(12):3294-300. 
Sažetak

\section{PRESKAČUĆE METASTAZE PAPILARNOG KARICINOMA ŠTITNJAČE - UČESTALOST, PREDIKTIVNI I KLINIČKO-PATOLOŠKI ČIMBENICI}

\section{B. Miličic, R. Prstačići D. Prgomet}

Uvod: Metastaze u limfnim čvorovima vrata čest su nalaz kod papilarnog karcinoma štitnjače i pojavljuju se određenim redoslijedom. Tzv. ,skip“ metastaze koje "preskaču” centralni odjeljak te se šire inicijalno u lateralne regije vrata mogu se naći u određenom broju tih pacijenata, a njihov značaj nije još dobro istražen. Cilj ove prospektivne studije jest identificirati njihove moguće prediktore i kliničko-patološke značajke u skupini pacijenata s lateralnim metastazama papilarnog karcinoma štitnjače. Metode: U studiju je bilo uključeno 68 pacijenata s papilarnim karcinomom kojima su prethodno verificirane lateralne metastaze te su bili podvrgnuti totalnoj tiroidektomiji uz lateralnu disekciju vrata, u razdoblju od 2011 do 2018 godine. Analizirane su i uspoređene kliničko-patološke značajke te obrazac metastaziranja kontinuiranih i skip metastaza. Rezultati: Učestalost skip metastaza bila je 23,5\%. U usporedbi sa skupinom s kontinuiranim metastazama, ti pacijenti bili su stariji, primarni tumori bili su rjeđe bilateralni, te su bili manjih dimenzija. Regija II bila je rjeđe zahvaćena, te nitko od tih pacijenata nije imao sve regije zahvaćene metastazama. Zaključak: Skip metastaze pojavljuju se češće u starijih pacijenata te pokazuju određene kliničko-patološke značajke kao što su manja dimenzija primarnih tumora, te diseminacija u manje lateralnih regija vrata. Uzevši u obzir da se takve metastaze relativno često susreću, lateralne regije vrata trebale bi se temeljito istražiti u pacijenata s papilarnim karcinomom štitnjače bez metastaza u centralnim odjeljcima vrata.

Ključne riječi: skip metastaze, papilarni karcinom štitnjače, kliničko-patološke značajke, lateralne metastaze vrata 